\title{
Islamic Economics: Contemporary Approach in the Arab World
}

\author{
Lica Madalina
}

PhD student, ASE Bucharest, madalina.lica@yahoo.com

\section{Doi:10.5901/ajis.2015.v4n3s1p278}

\begin{abstract}
In the context of the concerns raised regarding the cooperation with the Arab world, the challenge for international business is to respect the Islamic principles and values. Currently, religion in the Arab world begins to be seen rather as a constructive power than a destructive one. The present paper comprises a presentation of what Islamic financial system implies for the economies of Arab countries nowadays and a comparison between the performance of Islamic and conventional banks in Pakistan. It is shown that the Islamic banking system is reliable and may represent a strong competition for conventional banks in the Islamic world. In the Gulf countries where Islamic banking has begun to play an important role, a new type of Islamic capitalism is taking shape. In these countries, we can say that the development and economic diversification were sustained in a more appropriate manner than in North African countries, especially in Egypt, Libya and Algeria, where government policies were both anti-capitalist and against the implementation of the Islamic law sharia'a in finance and banking. The origins of "Islamic economics" are traced back to the writings of Savyd-Abul Ala Mawdudi, a Pakistani social thinker who wanted to transform Islam into a "completely new kind of life." The "Islamic way of life", a concept put forth by Mawdudi, which together with "Islamic Ideology", "Islamic politics", "Islamic constitution" have become key concepts in the discourses that support the spiritual renewal for Muslims and the introduction of the "Islamic economics" concept. In his writings, Mawdudi argues that Islam is more than a set of rituals. It includes all the areas of human life, for instance education, art, medicine, law, politics and economics. In order to prove his point, he laid the bases of several Islamic disciplines, among which "Islamic economics" is a notable one.
\end{abstract}

Keywords: Islamic economics, Islamic financial system, Arab world, sharia'a.

\section{Introduction}

In the context of the concerns raised regarding the cooperation with the Arab world, the challenge for international business is to respect the Islamic principles and values. Currently, religion in the Arab world begins to be seen rather as a constructive power than a destructive one. The present paper comprises a presentation of what Islamic financial system implies for the economies of Arab countries nowadays and a comparison between the performance of Islamic and conventional banks in Pakistan. It is shown that the Islamic banking system is reliable and may represent a strong competition for conventional banks in the Islamic world. In the Gulf countries where Islamic banking has begun to play an important role, a new type of Islamic capitalism is taking shape. In these countries, we can say that the development and economic diversification were sustained in a more appropriate manner than in North African countries, especially in Egypt, Libya and Algeria, where government policies were both anti-capitalist and against the implementation of the Islamic law sharia'a in finance and banking.

The research aims at analyzing the impact that Islamic economics has had on Arab countries. This has been achieved by studying the origins of Islamic economics, the most important writers who have influenced the concept and the problems it aims to solve. Islamic economics is specific to the Arab world and aims to provide a viable alternative to capitalism or socialism. The concept was initially the idea of spiritual rebirth and unification of Muslims, it developed further, reaching today to propose the introduction of a system different from the conventional banking system and a redistribution system quite atypical for the times we live in.

This idea, as well as the compatibility of Islam with businesses and a general presentation of Islamic economics are described especially in the first part of the research.

Part two involves the presentation of Islamic finance in the economies of Muslim countries nowadays and a comparison between the performance of an Islamic bank and several conventional banks in Pakistan. It is shown that the Islamic banking system is viable and represents even a strong competition for conventional banks in the Islamic world. 


\section{Theoretical Framework}

The origins of "Islamic economics" are traced back to the writings of Savyd-Abul Ala Mawdudi, a Pakistani social thinker who wanted to transform Islam into a "completely new kind of life." The "Islamic way of life", a concept put forth by Mawdudi, which together with "Islamic Ideology", "Islamic politics", "Islamic constitution" have become key concepts in the discourses that support the spiritual renewal for Muslims and the introduction of the "Islamic economics" concept. In his writings, Mawdudi argues that Islam is more than a set of rituals. It includes all the areas of human life, for instance education, art, medicine, law, politics and economics. In order to prove his point, he laid the bases of several Islamic disciplines, among which "Islamic economics" is a notable one.

Other contributions were made by Sayyid Qutb and Muhammad Baqir al-Sadr. The teachings of these pioneers differ in many respects. Mawdudi is adherent of the market economy, but insists that market behavior is constrained by the rigors of behavior found in classical sources of Islam. As a thinker who does not believe in the virtues of the free market, Qutb is in favor of market regulations by state intervention. The two thinkers are quite intolerant of economic inequality; therefore, their beliefs have not led to two completely different schools of thought such as Marxism and neoclassical school, for example. For several decades, the economy of Islam was merely a concept, an "intellectual exercise", but from 1970 it began to evolve being implemented by Islamic banks with zero interest and the redistribution system typical to Islam, the 'zakat'. Currently there are thousands of books and articles in dozens of languages about Islamic economics, Islamic banks in dozens of countries and conventional banks with Islamic banking departments including in the USA (Citicorp, Chase Manhattan Bank). The zakat was formally established in Saudi Arabia, Pakistan, Malaysia and some other countries.

Islamic economics is based on certain characteristics that distinguish it from other economic systems. Starting with Sayyid Abul A'la Mawdudi's views to fundamentalists's views nowadays, the most important feature is the prohibition of interest. Two other defining characteristics are the zakat system of redistribution of wealth and the requirement that any economic activity undertaken passes through the Islamic moral filter. Profit is only accepted as payment for risk taking, so it is considered unfair for a bank to benefit from an entrepreneur's loan when the latter's business can fail, but the bank can win money. Zakat is the redistribution system which collects a tax from wealthy Muslims to allow the funding of the eight "causes", including helping the poor Muslims. In addition to these defining "causes", citizens must act guided by certain rules drawn from traditional sources of Islam. Very briefly, these rules "enjoin good" and "forbid evil." The good is the individual's orientation towards the needs of society and the evil is represented by selfishness, avarice and ignoring the needs of the people less well-off around him. I will try to further outline how Islam is trying to report and solve these problems.

The first important, fundamental principle of Islam is that natural laws and principles of life and human nature should not interfere with anything and when there is a " deviation " from the path of nature, it should be " redirected ". The second important principle on which Islam relies its social reforms is that the introduction of external regulation should not be considered sufficient, but a greater emphasis should be put on moral reform and on creating moral attitudes.

The third principle is that the pressure of authority and the law should not be used unless it is truly inevitable. Given these principles, Islam recognizes (to the extent that this does not contradict the overall good of society) the human right to earn their livelihood according to skills and gifts, that man is the possessor of what he has won honestly, that it is normal to have differences between people in terms of capabilities and level of remuneration. What Islam does not recognize relates to law and related instruments to acquire livelihood that can lead to moral degradation or "spoil" the social order. Islam creates a distinction between what is halal (lawful) and haram (unlawful) regarding the different ways that someone can earn a living. Therefore, under Islamic law, wine and other drinks are not only unlawful (haram), but even the manufacture, sale, purchase and possession were declared as haram. Islam does not recognize prostitution, music and dance as the legal activities of making a living. Bribery, stealing, gambling, speculation, businesses based on fraud and deceit, making supplies and "hide" certain necessities of life only with a view to subsequently increase prices, monopoly or other such methods were also reported as illegal. There have also been declared illegal all forms of business, because due to their nature, they are capable of causing disputes in which the gain or loss depends simply on luck or mutual rights of the parties are indistinguishable. It is believed that if businesses takes place within it, there is a slight possibility that someone might accumulate huge wealth.

While Islam recognizes the property rights of each individual, it does not allow the completely free use of his fortune. On the other hand, restrictions are put on the three ways in which fortune can be used: spend, invested to accumulate more wealth or preserved. It can not be spent on things or actions that would harm the morals (like buying wine or gambling, for example). The best action that a good Muslim would possibly take is to secure a decent living, and 
if it remains somewhat of a surplus in its gain, then he should help the needy people who earn below the minimum wage and for whom fate was less generous. Islamic ethics will always respect those who earn more and spend much more than those who keep their wealth gathered or who prefer to invest their surplus in order to gather more.

Do we really need Islamic economics given that there is already a conventional economics at a high level? Can Islamic economics answer to some problems to which the traditional one cannot answer? Their study material is almost the same: the study of the allocation and distribution of scarce resources for alternative uses. Resources are limited and insufficient to meet all the requirements of all individuals and all groups of society.

\section{Methodology}

The case study that I will present and analyze below (Moin, 2008) aims to achieve a comparison between the performance of Islamic banks with those of conventional banks. For this purpose, I will compare the Islamic bank's performance Pakistani Meezan Bank Limited, with the average performances of five conventional banks operating also on the banking market of Pakistan, namely Kasba Bank Limited, Arif Habib Bank Limited, Bank Al Habib Limited, Faysal Bank Limited and Habib Bank Limited. In my analysis, I will focus on the performance of banks included in the sample based on the comparison of a set of financial indicators divided into four categories: ratios of profitability, liquidity, solvency and efficiency.

\section{Islamic Bank Performance Vs. Conventional Banks Performance}

As an overall assessment of the size of the banking system of Pakistan, it has to be mentioned that Pakistan has nowadays 54 banks and financial institutions, divided into public banks, private, Islamic and foreign specialized financial institutions. Over the past few years, the banking system was restructured along with the Pakistani capital liberalization, privatization of public banks and the application of prudential regulations. While in the early 1990 s, only $10 \%$ of financial system assets belonged to private banks, now they hold nearly $80 \%$. The foundations of the Islamic banking system development were established about three decades ago, in the mid 80s. Pakistan, along with Iran, adopted banking systems without interest, which have been recognized by the constitution (Mirakhor Iqbal, op. cit., p.383). An official initiative of this kind occurred when the State Bank Of Pakistan (SBP) in 2000 created the Commission of transformation of the financial system in order to support banks to introduce ways of financing in line with sharia'a. During this time, Islamic banks have enjoyed the most spectacular evolution of market share, increasing from $2 \%$ in the 70 s to $15 \%$ nowadays. Returning to the case studies analyzed, in January 2002, Meezan Bank Limited (MBL) has been granted the first Islamic banking license by SBP, and in September 2003, SBP created the Department of Islamic banking activities. MBL is the most experienced Islamic bank in Pakistan and this is what I took into consideration when choosing the representative Islamic bank.

\section{Profitability Ratios}

\subsection{Return on Assets : ROA, defined as the ratio between the net profit and the total banking assets}

ROA = Net Income / Net assets * 100

This rate gives an overall assessment of bank profitability. In developed countries, this rate has typically the values between $0.5-1 \%$. Very large banks record lower rates.

Regarding the potential significance : a decreasing trend shows that the bank is in difficulty, a growing trend is the expression of positive results, but it may be the expression of excessive risk taken by the bank.

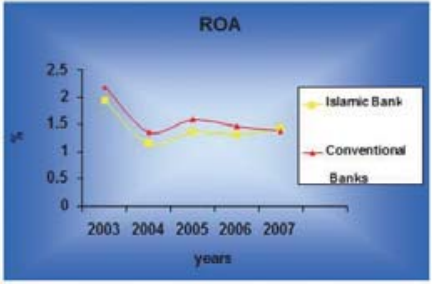

Figure 1

Source: Muhhamad Shehzad Moin, Performance of Islamic Banking and Conventional Banking, pp. 26 
It can be seen that conventional banks' ROA was slightly higher than the Islamic bank's ROA, except in 2007, the Islamic bank's ROA easily surpassed that of conventional banks, $1.43 \%$ versus $1.38 \%$. Banks also followed the same type of trend, a difference of about 0.20 points to 2006. The banking sector in Pakistan is growing, but considering recent years, both banks are facing difficulties in profitability.

5.2 Return on equity: ROE, defined as the ratio between net profit and equity. It gives practical expression of profits in capital.

$\mathrm{ROE}=$ Net profit / Equity * 100 the typical value of this rate is $10-12 \%$. A higher rate of return can be the effect of a small capital or the expression of increased capacity to obtain, by lending, additional resources.

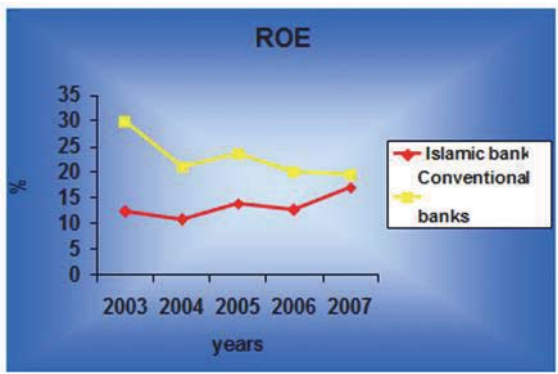

\section{Figure 2}

Source: Muhhamad Shehzad Moin, Performance of Islamic Banking and Conventional Banking, pp. 27

Even if the average return on equity of conventional banks is considerably higher than the Islamic bank's $22.76 \%$ versus $13.27 \%$, however the difference of 2 percentage points existing in 2007 , is a hope that the Islamic Bank may reach at least the same financial return as the conventional ones.

1.3 Rate Price / Earnings (PER; Price / Earnings Ratio): Also called the coefficient of market capitalization. Price / earnings prospects indicate investors' perceptions of the company. Essentially, it is a financial ratio of the market value of the company in question, showing how much investors are willing to pay for the current gain.

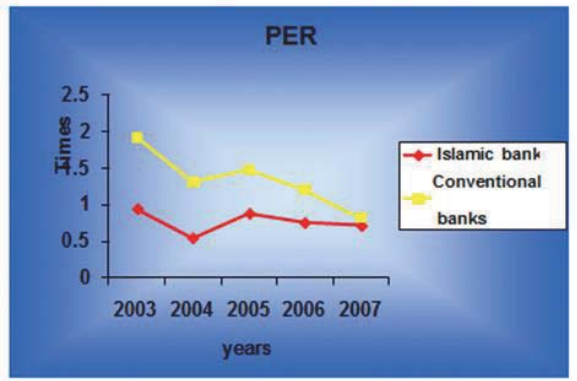

\section{Figure 3}

Source: Muhhamad Shehzad Moin, Performance of Islamic Banking and Conventional Banking, pp. 28

Liquidity Rate (Loan to deposit ratio / LDR) LDR is the most important factor which measures bank liquidity. Since it is forbidden to lend money with interest, the only way in which Islamic banks can use the facilities is to provide funding through various Islamic products. Banks with a low LDR are considered to have high liquidity, perhaps low returns and therefore lower risk to a bank with a higher LDR. On the other hand, a high LDR shows that the bank has assumed more financial risks that gave many loans. 


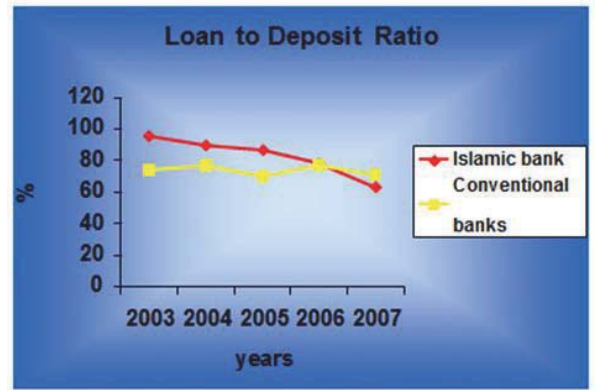

\section{Figure 4}

Source: Muhhamad Shehzad Moin, Performance of Islamic Banking and Conventional Banking, pp. 29

Relatively high LDR rates of Islamic bank in the period 2003-2006 show that this was relatively less liquid compared with traditional banks. In 2007, however, the Islamic bank has become more fluid than the conventional banks, reaching a rate of $63.35 \%$ against $70.89 \%$. This trend of decreasing LDR coefficient shows an increasing trend of deposits to loans and therefore stresses improving Islamic bank liquidity. Although during the 5 years the Islamic bank's LDR shows an increased liquidity of conventional banks compared to Islamic bank, the latter continues to show encouraging development prospects.

\section{The Solvency Ratios}

Multiplier Equity ( Equity Multiplier: EM ) EM = Total Assets / Equity capital EM is an indicator which highlights the degree to which the use of additional funds raised increase return on equity. In general, the higher this ratio is, the greater is the risk that the bank will incur.

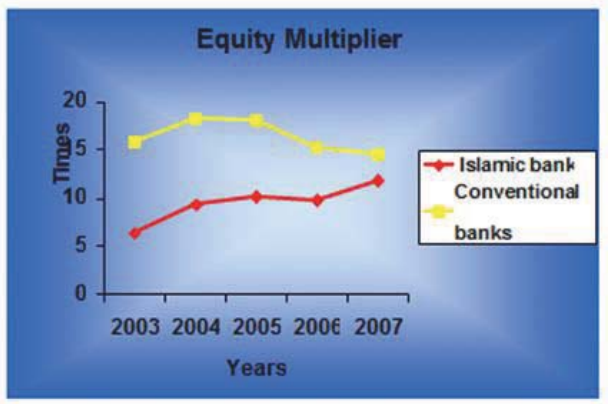

\section{Figure 5}

Source: Muhhamad Shehzad Moin, Performance of Islamic Banking and Conventional Banking, pp. 32

The analysis of other measures of risk capital multiplier confirms that conventional banks are riskier and less liquid than those of Islamic bank.

\section{Efficiency Rate}

The rotation speed of total assets (Total Assets Turnover ( TAT ) / Assets Utilization (AU) AU = Income / Total assets AU is calculated as a ratio between the total income from banking operations and total assets and shows total revenues are obtained from the use assets (interest income, fees, income taxes and non-profit ). If they have a high value, then it can be said that the bank effectively uses its assets to generate earnings. If the AU is low, then the bank does not use its assets to its capacity and should be able to increase its revenue to waive some of the assets. 


\section{Figure 6}

Source: Muhhamad Shehzad Moin, Performance of Islamic Banking and Conventional Banking, pp. 34

Conventional banks and Islamic bank followed approximately the same trend, Islamic. This means that even if the Islamic bank has improved its performance, it continues to be below conventional banks.

4.2. Operating efficiency ratio (Operating efficiency = Operational Expenses / Operating Revenues) Unlike EIR, which measures income earned per unit cost, $\mathrm{OE}$ is the ratio which measures operating expenses per unit of operating revenues. $\mathrm{OE}$ translates into managerial efficiency in generating operational revenues and controlling operational expenditure, in other words, how effective is the bank in its operations. A lower efficiency rate is preferable than a higher rate, because in the latter case the indicator shows that operational costs are too high in relation to operating income.

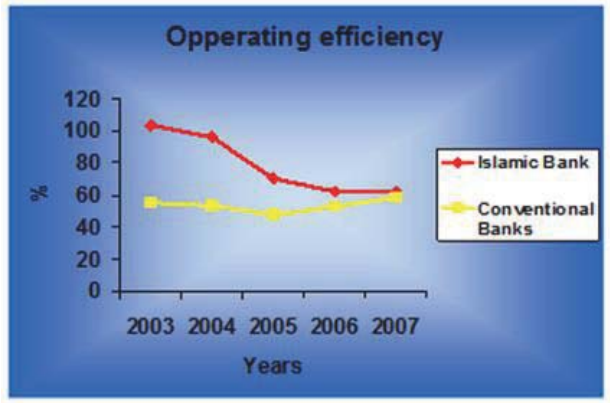

\section{Figure 7}

Source: Muhhamad Shehzad Moin, Performance of Islamic Banking and Conventional Banking, pp. 36

The difference between conventional and Islamic banks was very high in $2003,103.39 \%$ compared to $54.95 \%$. However, it has decreased considerably, reaching $62.23 \%$ in 2007 to $58.72 \%$. The third indicator shows, again, the efficiency of conventional banks which is higher than that of the Islamic bank, with a 5-year average of $78.78 \%$ to $53.51 \%$.

\section{Results Obtained}

The evolution rates of profitability show that conventional banks are more profitable than the Islamic bank. However, the Islamic bank is constantly improving its performance through profitable investments it carries as well as greater control over operational expenses, managing to increase dividends to its shareholders. In recent years, the Islamic bank has become more liquid than the conventional ones, both in terms of LDR and CPIDBR (in fact, according to this rate, the Islamic bank was always more liquid than the conventional ones). Overall, the debt ratio analysis results show that conventional banks are riskier and less creditworthy than Islamic banks. Regarding efficiency rates, the Islamic bank is less efficient in using its assets in generating revenue and managing expenditure, but it has considerably improved activity over time and it is estimated that it will improve in the future.

\section{Conclusions}

Although Islamic banks have the theoretical support to be considered a viable alternative to conventional banks, they still 
have several "challenges" to overcome. The challenges can be divided into two broad categories: the financial ones that require new techniques through which the Islamic finance principles should be implemented and which should ensure the efficiency and stability of the system operability and its integration into the international capital market. Financial innovations are necessary to meet short and long term market needs. A challenging financial subject is to introduce new products compatible with sharia to ensure market liquidity and provide the necessary tools for risk management and portfolio diversification.

In conclusion, in terms of business environment, the Muslim world asks to adapt and meet the same conditions without discrimination between the status of multinational corporations and the local businesses, the requirement being that Muslim customers, employees and suppliers to be satisfied by their business practices. The incompatibility between Islam and modernization is a reality, but this incompatibility tends to mitigate, as religion in the Muslim world begins to be seen rather as a constructive power than a destructive one.

Viewed from outside Islam, the significance of these developments is that, amid concerns for cooperation rather than confrontation with the Muslim world, the big challenge for international business will be to respect Islamic values and to better utilize the skills and enthusiasm of Muslim employees.

\section{Acknowledgement}

This work was financially supported through the project "Routes of academic excellence in doctoral and post-doctoral research - READ" co-financed through the European Social Fund, by Sectoral Operational Programme Human Resources Development 2007-2013, contract no POSDRU/159/1.5/S/137926.

\section{References}

Chapra, Umer (2000): Is it necessary to have Islamic Economics?, Journal of Socio-Economics, pp. 21-37.

Kuran, Timur (1997): The Genesis of Islamic Economics, Social Research, Vol. 64, No. 2.

Hossein Askari, Zamir Iqbal, Abbas Mirakhor (2009): New Issues in Islamic Finance and Economics: Progress and Challenges.

Maududi, Abul A'la (1941): The economic problem of man and its Islamic solution, Lahore (Pakistan), Islamic Publications.

Moin, Muhhamad Shehzad: Performance of Islamic Banking and Conventional Banking in Pakistan: A Comparative Study, Master Degree Project in Finance, Spring Term 2008

Oslington, Paul (2003): Economics and Religion, Vol.I + II, Cheltenham/UK, Edward Elgar Publishing Limited.

Socaciu-Binţinţan, Anca (2010): Sistem de analiză bancară, Teză de doctorat (Universitatea "Babeş-Bolyai" Cluj-Napoca. Facultatea de Ştiinţe Economice şi Gestiunea Afacerilor)

Thor Pleter, Octavian (2005): Administrarea afacerilor, Bucureşti, Carta Universitară.

Tomiţ̧ă,T., Paraipan,L., Grumăzescu,A., Vanghelescu,A. (2004): Diç̧ionar de management al riscului, Bucureşti, BRM Business Consulting.

Wilson, Rodney (2006): Islam and business, Thunderbird International Business Review 48(1): 109-123. 